\title{
DISTRIBUTION CHARACTERISTICS OF FERRO-TITANIUM OXIDE MINERAL ON LOW-GRADE IRON SAND
}

\author{
KARAKTERISTIK DISTRIBUSI MINERAL BESI-TITANIUM \\ OKSIDA PADA PASIR BESI KADAR RENDAH
}

\author{
SURATMAN \\ Research \& Development Centre for Mineral and Coal Technology \\ Jalan Jenderal Sudirman 623 Bandung 40211 \\ Ph. (+6222) 6030483, Fax. (+6222) 6003373 \\ e-mail: suratman@tekmira.esdm.go.id
}

\begin{abstract}
Iron sand is known as one of the sources of $\mathrm{TiO}_{2}$ in the form of ilmenite or titanomagnetite mineral. Irontitanium oxide mineral contained in Indonesia iron sand are classified as titanomagnetite. Indonesia possesses a lot of iron sand deposits such as at southern coast of Cilacap, Kebumen and other areas. The iron sand consists of magnetic and non-magnetic minerals as either loses or bound materials. Fractionation of Cilacap iron sand which employed three types of sieve (40, 60 and 80 meshes) showed that the iron sand is dominant in $-40+60$ fraction $(68.38 \mathrm{~g})$ while the most amount of iron and titania contents occurred at fraction of -80 mesh, namely 11.62 and $1.46 \%$. Magnetic separation showed that the finer the particles and the higher the magnetic intensity, the higher the derived iron and titania. The process has also successfully increased the $\mathrm{TiO}_{2}$ content more than 5 times, from 0.325 to $1.67 \%$.
\end{abstract}

Keywords: iron sand, particle size, magnetic separation, titanium oxide.

\begin{abstract}
ABSTRAK
Pasir besi dikenal sebagai salah satu sumber $\mathrm{TiO}_{2}$ baik dalam bentuk mineral ilmenite atau titanomagnetite. Mineral Oksida besi-titanium yang terkandung dalam pasir besi Indonesia diklasifikasikan sebagai titanomagnetit. Indonesia mempunyai potensi pasir besi cukup banyak seperti di pantai selatan Cilacap, Kebumen dan daerah lainnya. Dalam pasir besi tersebut terkandung mineral magnetik dan bukan magnetik baik yang bersifat lepas maupun berasosiasi dengan mineral lain. Fraksinasi pasir besi Cilacap dengan tiga jenis ayakan (40, 60 dan 80 mesh) menunjukkan bahwa pasir besi dominan pada fraksi -40+60 mesh (68,38 gram) sedangkan kandungan besi dan $\mathrm{TiO}_{2}$ terbanyak ada pada fraksi lolos 80 mesh, yaitu masing-masing 11,62 dan 1,46\%. Separasi secara magnetik menunjukkan bahwa semakin halus ukuran partikel dan semakin tinggi intensitas magnetik yang digunakan semakin tinggi kadar besi dan titanium oksida yang diperoleh. Proses ini telah berhasil meningkatkan kandungan $\mathrm{TiO}_{2}$, lebih dari lima kali lipat, yaitu dari 0,325\% menjadi 1,67\%.
\end{abstract}

Kata kunci: pasir besi, ukuran partikel, pemisahan magnetik, titanium oksida.

\section{INTRODUCTION}

Titanium dioxide $\left(\mathrm{TiO}_{2}\right)$, also known as titanium (IV) oxide or titania, is a metal oxide that has a wide range of applications, from paint to sunscreen to food coloring due to its excellent characters such as white massive crystal, non-toxic and environmental friendly as well as insoluble in water (Justicia et al., 2002; Beer et al., 2015; Shaheed and Hussein, 2015; Sprong et al., 2015). The oxide is also used for making titanium metal. Such a metal is widely employed for making fighter aircraft, gas and chemical instruments, 
sports equipment, bike frame, jewelry, automotive, and medical equipment. The most important and strategic application of pure titanium and its alloy is in the airframe and aircraft engine industries (Barlow, 2015; Bedinger, 2015; Adams, 2016; Whitfield et al., 2016). The titanium is alloyed with other metals such as aluminum, chrome, zirconium, etc.

The need of $\mathrm{TiO}_{2}$ for the global market is predicted $4-7 \%$ through 2019, each year. Such a consumption notably goes to pigment industries and as the feed for titanium making. It is assumed that in 2025, the demand of total $\mathrm{TiO}_{2}$ is up to 10.8 million ton. In 2015, the total demand of $\mathrm{TiO}_{2}$ was reported up to 7.055 million tons. It was assumed that the increase of the total $\mathrm{TiO}_{2}$ demand reached $5 \%$ a year. The deficit of such a material will occur in 2017 as the global production for $\mathrm{TiO}_{2}$ is predicted up to 7.5 million tons and no significant increase of $\mathrm{TiO}_{2}$ production through 2017 (Barlow, 2015; Bedinger, 2015; Adams, 2016; Whitfield et al., 2016).

The main feedstocks for production of titanium dioxide pigment currently used by commercial processes in the form of titania slag (high $\mathrm{TiO}_{2}$ slag. The most common method for producing titania slag is smelting process which reduces iron oxides to liquid iron in large electric arc furnaces with raw material from ilmenite ore. The main product of smelting is titania slag containing approximately 75 to $85 \% \mathrm{TiO}_{2}$ (Middlemas, Fang and Fan, 2013; Gázquez et al., 2014).

Few $\mathrm{TiO}_{2}$-bearing minerals that are commercially used include ilmenite $\left(\mathrm{FeTiO}_{3}\right)$, leucoxene $\left(\mathrm{Fe}_{2} \mathrm{TiO}_{5}\right)$, rutile $\left(\mathrm{TiO}_{2}\right)$, ulvöspinel $\left(\mathrm{Fe}_{2} \mathrm{TiO}_{4}\right)$ and iron sand (Premaratne and Rowson, 2004; Babu, Vasumathi and Rao, 2009; Arndt, Kesler and Ganino, 2015). The iron sand is actually the beach sand that serves as the source of iron oxide and titanium oxide. Such the beach sands came from metamorphic and igneous rocks. There are two kinds of beach sand in nature, namely titanohematite and titanomagnetite. The former belongs to a mixture of ilmenite $\left(\mathrm{FeTiO}_{3}\right)$ and hematite $\left(\mathrm{Fe}_{2} \mathrm{O}_{3}\right)$ while the later contains ulvöspinel or ulvite $\left(\mathrm{Fe}_{2} \mathrm{TiO}_{4}\right)$ and magnetite $\left(\mathrm{Fe}_{3} \mathrm{O}_{4}\right)$. Indonesia possesses titanium resources that come from the iron sand. Its type belongs to titan magnetite with various $\mathrm{TiO}_{2}$ content. $\mathrm{TiO}_{2}$ levels generally found in deposits of titanomagnetite iron sand with levels ranging between 0,5-15\% $\quad \mathrm{TiO}_{2}$ (Tampubolon, 2013). Currently, Indonesian iron sand is only used as a mixture of Portland cement. The material is not optimally used as a potential commodity of metal mineral although the technology for processing the Indonesian titanomagnetite has been found. Such a technology, namely pyrometallurgy, processes the sand into titania slag. However; the sand should be concentrated prior to processing it as the feed to obtain titania (Zhang, Zhu and Cheng, 2011).

The success of iron sand concentration depends on iron sand characteristics. Ansori (2013) who processed the iron sand from the southern coast of Kebumen Regency by a magnetic separator obtained the recovery of $66.46 \%$ by weight with Fe total of 56.57 $\%$. Condition used by Ansori (2013) was 200 Gauss of magnetic intensity and $-120+120$ mesh of particle size. The iron sand used in this study came from the southern coast of Cilacap and had been characterized its mineralogy, chemical and concentration. The magnetic separator was used in terms of concentrating the material. Parameters used for magnetic separator were particle size distribution and magnetic intensities of iron and titanium-containing sands. The purpose of all characterization study was determining the right concentration process for obtaining optimum $\mathrm{TiO}_{2}$ concentrates.

\section{METHODOLOGY}

Samples used for this research came from Cilacap coastal which were prepared prior to mineral characteristic analyses and processing trial to get the concentrates. Figure 1 illustrated sample preparation of Cilacap iron beach sand for the research.

A series of preparation included washing, sampling and magnetic separation. The purpose of washing was to get rid of fine components such as clay while sampling contained quartering and splitting to get the representative samples. Magnetic separation was conducted using magnetic intensities of 1000, 2000 and 4000 Gausses. All preparation processes were shown in Figure 2. 




Figure 1. A flow chart of iron sand preparation

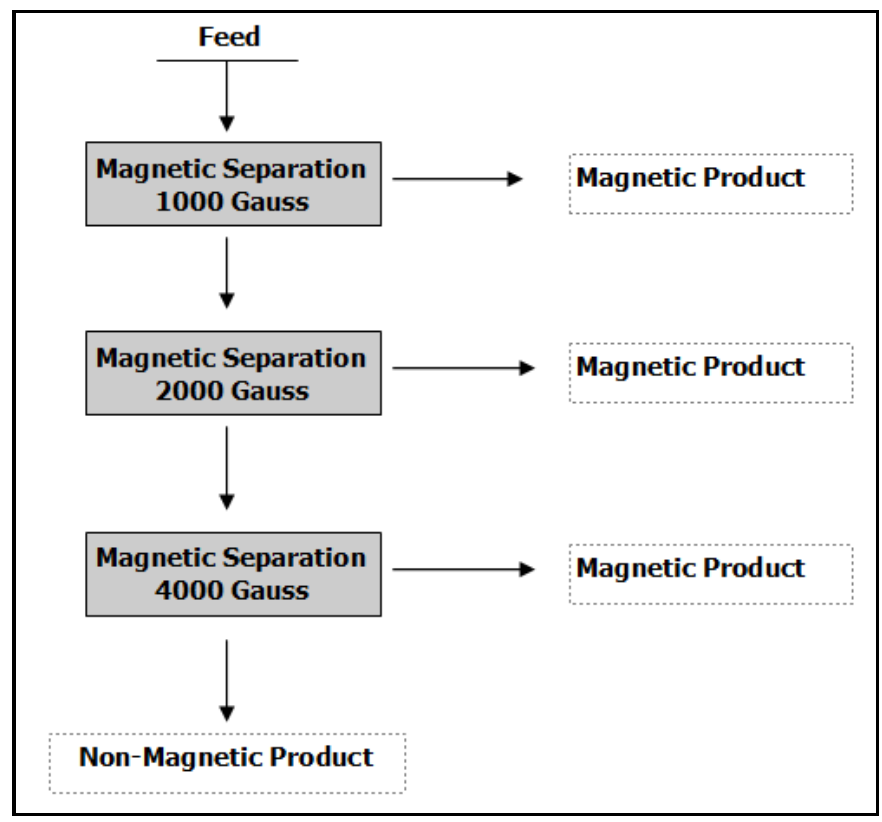

Figure 2. A flow chart for magnetic separation

\section{RESULTS AND DISCUSSION}

Sieve analysis of the $12,626 \mathrm{~kg}$-samples distributed the materials into four size fractions, namely $+40,-40+60,-60+80$ and 80 meshes as shown in Table 1 . Of the four sieve equipment, sieve $-40+60$ mesh maintained the highest weight percentage for all sieved samples. Each fraction was analyzed its total iron as well as its titanium dioxide contents. The result was presented in Table 2.

Titanium is actually an impurity element within the iron sand. The element needs to be physically separated in order to 
conventionally processing the sand by pyrometallurgy method. Yet the interlocking character between the iron and the titanium is a problem. The physical method cannot separate both materials (Sunaryo and Sugihartono, 2010; Sufiandi, 2011). Magnetic separation was conducted into 3 stages based on the employed magnetic intensities during the process. Such intensities included 1000, 2000 and 4000 Gausses. Of the four fractions, -80 mesh fraction was not processed. Chemical analyses were conducted to magnetic separation products to evaluate the total iron components and titanium oxide within the fractions. Table 3 illustrated such compositions. Magnetic separation products were also assessed its mineralogical composition using XRD method. However, the tested samples were a little bit different from those for chemical analyses.

Analyzing the dominant mineral within the product of magnetic separation was conducted using XRD method. The analyzed samples included an original sample of -80 mesh, magnetic product of $1.00 \mathrm{~g}$ size $-40+60$ and $-60+80$ meshes as well as non-magnetic product size $-40+60$ mesh. Figure 3 through 6 showed the XRD test for 4 samples.

Table 1. Results of sieving analyses for $12,626 \mathrm{~kg}$ Cilacap iron sand

\begin{tabular}{|c|c|c|c|c|c|c|c|c|c|c|}
\hline \multirow{3}{*}{$\begin{array}{l}\text { Particle size } \\
\quad \text { (mesh) }\end{array}$} & \multicolumn{8}{|c|}{ Weight of Sample code } & \multirow{2}{*}{\multicolumn{2}{|c|}{ Total }} \\
\hline & \multicolumn{2}{|c|}{ S1 } & \multicolumn{2}{|c|}{ S2 } & \multicolumn{2}{|c|}{ S3 } & \multicolumn{2}{|c|}{ S4 } & & \\
\hline & $\mathrm{g}$ & $\%$ & $\mathrm{~g}$ & $\%$ & $\mathrm{~g}$ & $\%$ & $\mathrm{~g}$ & $\%$ & $\mathrm{~g}$ & $\%$ \\
\hline+40 & 197 & 6.24 & 154 & 5.21 & 170 & 5.38 & 147 & 4.39 & 668 & 5.29 \\
\hline$-40+60$ & 2,233 & 70.62 & 2,020 & 68.38 & 2,172 & 68.69 & 2,230 & 66.61 & 8,655 & 68.55 \\
\hline$-60+80$ & 635 & 20.08 & 685 & 23.19 & 721 & 22.80 & 855 & 25.54 & 2,896 & 22.94 \\
\hline-80 & 97 & 3.07 & 95 & 3.22 & 99 & 3.13 & 116 & 3.46 & 407 & 3.22 \\
\hline Total & 3,162 & 100 & 2,954 & 100 & 3,162 & 100 & 3,348 & 100 & 12,626 & 100 \\
\hline
\end{tabular}

Table 2. Chemical composition of Cilacap iron sand based on each fraction

\begin{tabular}{cccc}
\hline \multirow{2}{*}{$\begin{array}{c}\text { Particle Size } \\
\text { (mesh) }\end{array}$} & \multicolumn{3}{c}{ Chemical Composition (\%) } \\
\cline { 2 - 4 } & Fe total & $\mathrm{TiO}_{2}$ & Wt. \\
\hline+40 & 3.37 & 0.45 & 5.29 \\
$-40+60$ & 2.91 & 0.39 & 68.55 \\
$-60+80$ & 4.75 & 0.77 & 22.94 \\
-80 & 11.62 & 1.46 & 3.22 \\
\hline
\end{tabular}

Table 3. Chemical compositions of magnetic separation products

\begin{tabular}{ccccccccc}
\hline \multirow{3}{*}{ Magnetic Products } & \multicolumn{3}{c}{ Total iron content within } & \multicolumn{4}{c}{$\mathrm{TiO}_{2}$ content within } \\
\cline { 2 - 9 } & $\begin{array}{c}+40 \\
\text { mesh }\end{array}$ & $\begin{array}{c}-40+60 \\
\text { mesh }\end{array}$ & $-60+80$ mesh & $\begin{array}{c}-80 \\
\text { mesh }\end{array}$ & $\begin{array}{c}+40 \\
\text { mesh }\end{array}$ & $\begin{array}{c}-40+60 \\
\text { mesh }\end{array}$ & $\begin{array}{c}-60+80 \\
\text { mesh }\end{array}$ & $\begin{array}{c}-80 \\
\text { mesh }\end{array}$ \\
\hline $1000 \mathrm{G}$ & 7.24 & 10.26 & 14.39 & - & 1.46 & 1.74 & 2.28 & - \\
$2000 \mathrm{G}$ & 5.14 & 7.27 & 10.49 & - & 0.97 & 1.57 & 1.59 & - \\
$4000 \mathrm{G}$ & 3.86 & 4.73 & 7.64 & - & 0.79 & 0.68 & 1.06 & - \\
Non-Mag & 1.96 & 2.22 & 3.47 & - & 0.44 & 0.25 & 0.57 & - \\
Original Sample & 3.37 & 2.91 & 4.75 & 11.62 & 0.45 & 0.39 & 0.77 & 1.46 \\
\hline
\end{tabular}




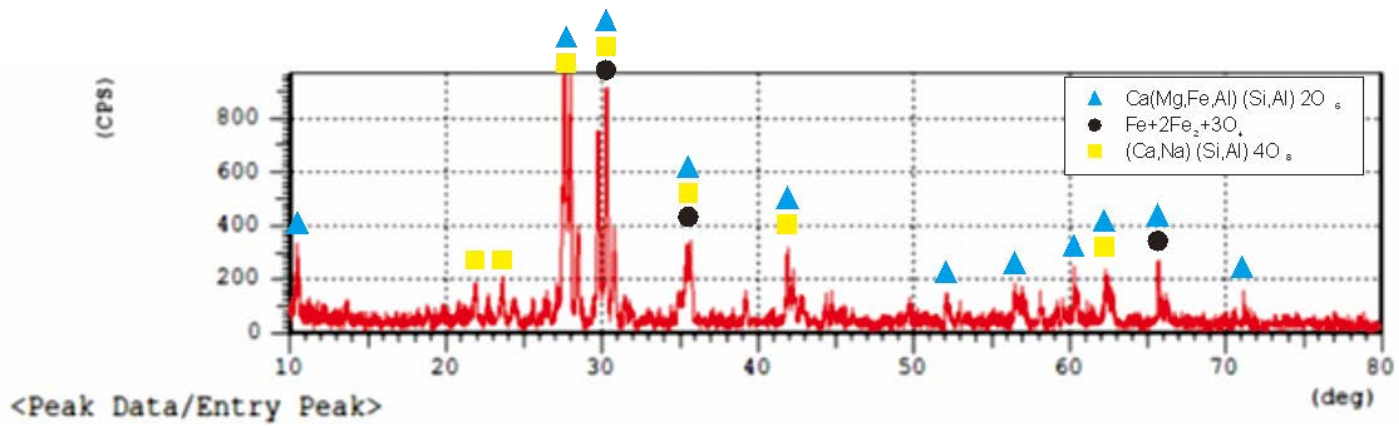

Figure 3. XRD histogram for origin sample size -80 mesh

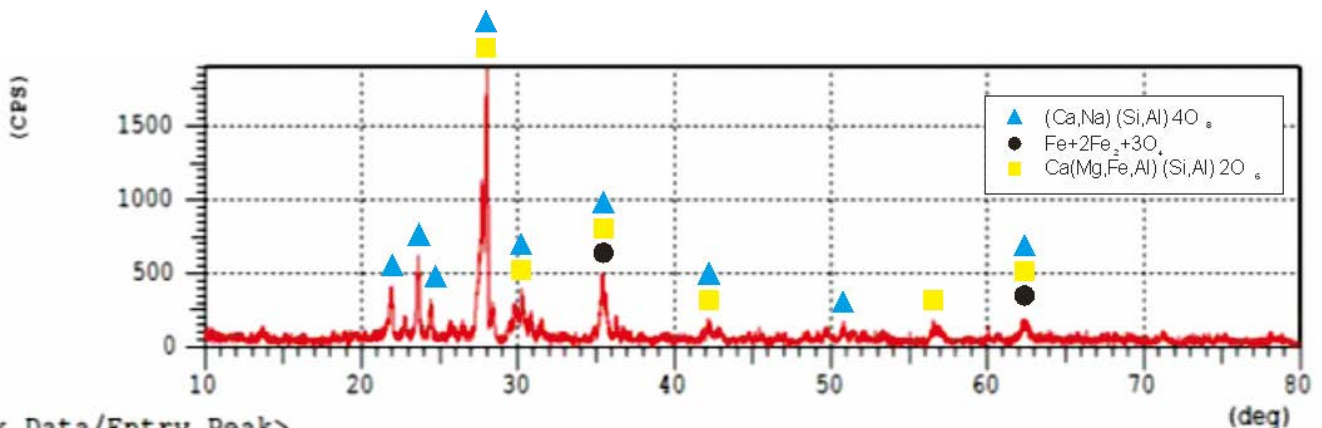

<Peak Data/Entry Peak>

Figure 4. XRD histogram for 1000 G-magnetic product, size-40+60 mesh

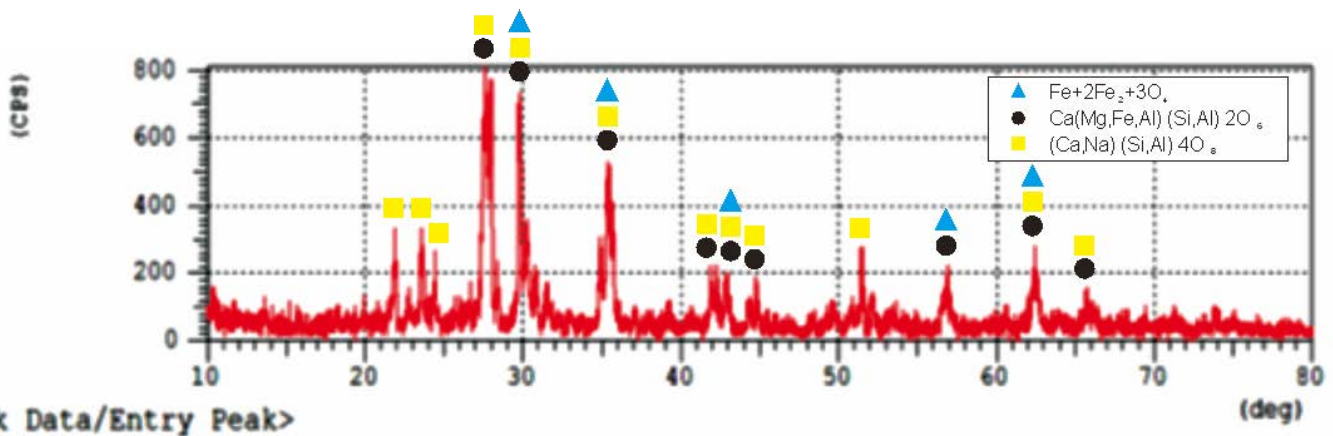

Figure 5. XRD histogram for 1000 G-magnetic product, size-60+80 mesh

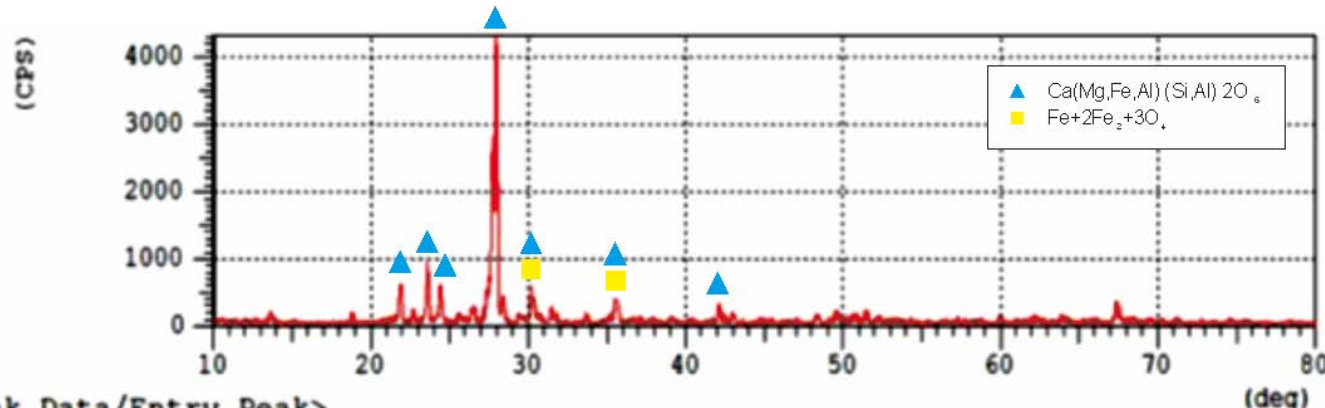

<Peak Data/Entry Peak>

Figure 6. XRD histogram for 1000 G-non-magnetic product, size-40+60 mesh 
Table 2 presented relation among particle size, percent weight of each tested sizes and total iron of each fraction. The table showed that size $250 \mu \mathrm{m}$ or 60 mesh was the dominant one retaining weight of $68.55 \%$ and the iron content of $54.85 \%$. This implied that the iron mineral was dominantly distributed at minus 60 mesh while the highest iron content was available at minus 80 mesh performing the content of $11.62 \%$ but its percentage weight was only $3.22 \%$. Figure 7 illustrated the particles size -60 mesh and -80 mesh. The former retained iron content of $2.91 \%$ while the later contained the iron of $11.62 \%$. Based on its performance, the iron sand with -60 mesh was lighter in color than that of -80 mesh. The amount of silica content within the -60 mesh size was supposed to be the reason why such sands comprised light color.

Effect of particle size on the derived magnetic separation products was shown in Figure 8. Of the three magnetic intensities used in magnetic separation processes; it seemed that the higher the used magnetic intensity, the lesser the derived weights. A particle with the size of $-40+60$ mesh that retained $68.55 \%$ provided the highest nonmagnetic products compared to other particle sizes. Yet for $4.000 \mathrm{G}$, the particles with a size of +40 mesh produced higher magnetic products than that of size $-40+60$ and $-60+80$ meshes. A similar case occurred to other sizes, the $4.000 \mathrm{G}$ gave magnetic products higher than that of 1.000 and 2.000 Gausses.

Referring to the analysis results for the distribution of total iron and titanium oxide, particle size and magnetic intensity; it is clear that the finer particle size the higher the quantities of both total iron and titanium oxide as shown in Figure 9. The figure also showed that the increase of total iron content was also followed by the increase of titanium oxide. The fact that the multiple increases of both materials were almost the same indicated that the iron and titanium minerals were still unified. The liberation degree between both minerals was still low. As a result, it was difficult to obtain magnetic products with high iron content but low $\mathrm{TiO}_{2}$ matter in coarser particles.

Table 4. Particle distribution and iron content of Cilacap iron sand

\begin{tabular}{ccccccc}
\hline \multicolumn{2}{c}{ Particle Size } & Weight & $\begin{array}{c}\text { Total iron } \\
\text { content }\end{array}$ & $\begin{array}{c}\text { Distribution of } \\
\text { total iron content }\end{array}$ & $\begin{array}{c}\text { Cumulative weight } \\
\text { of retained particles }\end{array}$ & $\begin{array}{c}\text { Cumulative weight of } \\
\text { total iron content }\end{array}$ \\
\hline (mesh) & $\boldsymbol{\mu} \mathbf{~ m}$ & $\%$ & $\%$ & $\%$ & $\%$ & $\%$ \\
+40 & 420 & 5.29 & 3.37 & 4.90 & 5.29 & 4.90 \\
$-40+60$ & 250 & 68.55 & 2.91 & 54.85 & 73.84 & 59.75 \\
$-60+80$ & 177 & 22.94 & 4.75 & 29.96 & 96.78 & 89.71 \\
-80 & $?$ & 3.22 & 11.62 & 10.29 & - & 100 \\
& & 100 & 3.637 & 100 & - & - \\
\hline
\end{tabular}

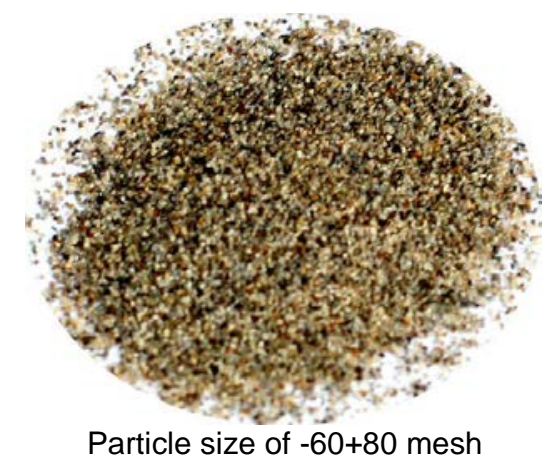

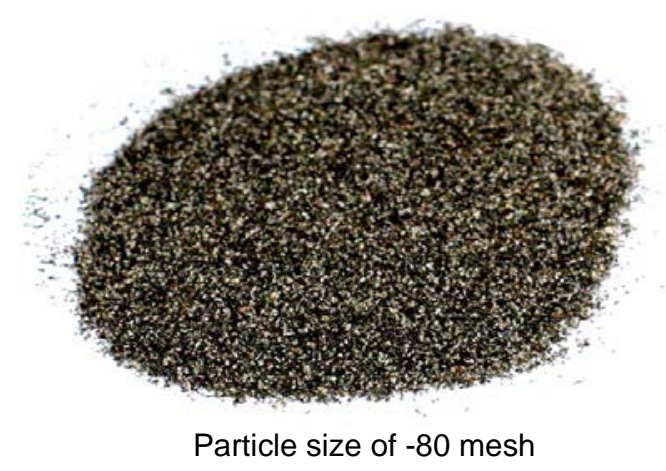

Figure 7. Illustration of iron sand particle, size $-60+80$ and -80 meshes 




Figure 8. Effect of particle size on the weight percent of magnetic separation products.

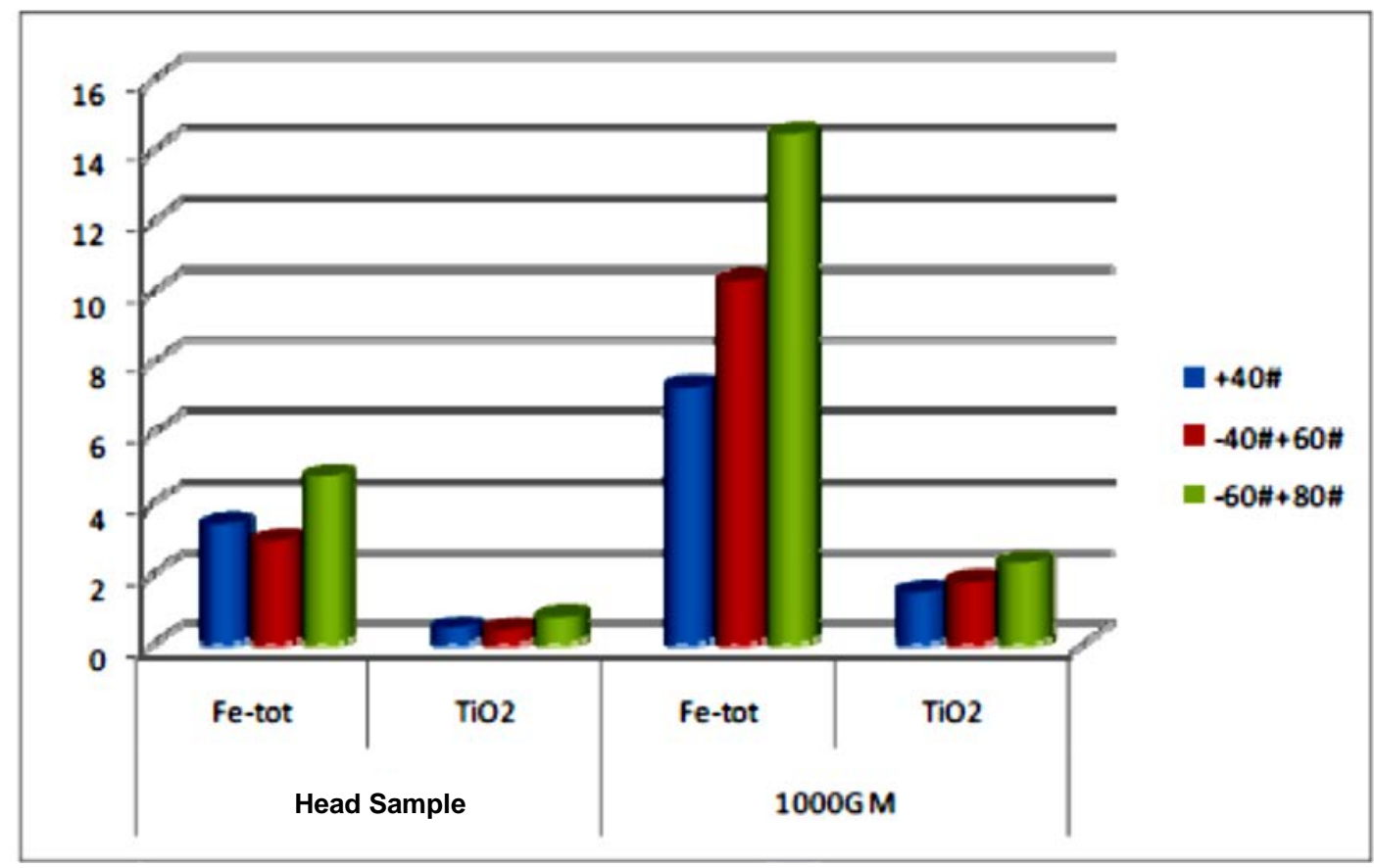

Figure 9. Effect of particle size on the recovered total iron and titanium oxide in magnetic separation.

The contents of both iron and titanium compositions in either original and product samples were the same. Both retained low contents. Geological condition affirmed that the samples came from the low-content iron deposit. Sunaryo and Sugihartono (2010) who analyzed titanomagnetite from iron sand using magnetic intensity of 1.3 Tesla, succeeded to increase the iron sand up to $82.25 w t \%$ though the feed for magnetic separator came from different locations. Referring to such condition, the original 
samples needed to be examined in detail other valuable components. Commonly, the iron sand contained trace elements such as vanadium.

Based on XRF analysis (Table 5), vanadium pentoxide $\left(\mathrm{V}_{2} \mathrm{O}_{5}\right)$ was detected within magnetic separation products. Such the products, included the magnetic product of ($60+80 \#, 1000 \mathrm{G})$ and the nonmagnetic one of $(-40+60 \#, 4000 \mathrm{G})$, performed the contents of $0.089 \%$ and $0.011 \%$ respectively. The two products were selected to be reviewed their rare elements due to its high contents of their iron oxides (14.39\%) and percent weight (77.2\%). Yet the analysis also detected other rare element oxides namely strontium and gallium oxides. Sample with the code of 60+80 mesh/1000G/M showed SrO concentration of $0.033 \%$ while within the sample $-40+60 \mathrm{mesh} / 4000 \mathrm{G} / \mathrm{NM}$, the $\mathrm{SrO}$ was $0.118 \%$. It seemed that the amount of this element in the later sample (nonmagnetic products) was bigger than that of the former sample (magnetic product). Strontium oxide was normally used for cathode ray tubes to block X-ray emission. A similar condition also occurred to gallium oxide; the magnetic sample retained less concentration compared to non-magnetic ones. Commonly, the metal was employed for semiconductors, alloys and biomedical applications.

Of the four samples identified by XRD method, all samples showed similar contents, namely magnesium calcium aluminum iron silicate - $\left[\mathrm{Ca}(\mathrm{Mg}, \mathrm{Fe}, \mathrm{Al})(\mathrm{Si}, \mathrm{Al})_{2} \mathrm{O}_{6}\right]$, magnetite $\mathrm{Fe}_{3} \mathrm{O}_{4}$, sodium calcium aluminum silicate $(\mathrm{Ca}, \mathrm{Na})(\mathrm{Si}, \mathrm{Al})_{4} \mathrm{O}_{8}$ (Table 6). All products contained magnetite, including the nonmagnetic one.

Table 5. Results of XRF analyses for magnetic and non-magnetic products of Cilacap iron sand after magnetic separation process.

\begin{tabular}{ccccccccccccccccc}
\hline Sample Code & \multicolumn{110}{c}{ Chemical Composition } \\
\cline { 2 - 13 } & $\mathrm{SiO}_{2}$ & $\mathrm{TiO}_{2}$ & $\mathrm{Al}_{2} \mathrm{O}_{3}$ & $\mathrm{MnO}$ & $\mathrm{CaO}$ & $\mathrm{MgO}$ & $\mathrm{K}_{2} \mathrm{O}$ & $\mathrm{P}_{2} \mathrm{O}_{5}$ & $\mathrm{Fe}_{3} \mathrm{O}_{4}$ & $\mathrm{ZrO}_{2}$ & $\mathrm{SrO}$ & $\mathrm{V}_{2} \mathrm{O}_{5}$ & $\mathrm{Cr}_{2} \mathrm{O}_{3}$ & $\mathrm{CO}_{3} \mathrm{O}_{4}$ & $\mathrm{Ga}_{2} \mathrm{O}_{3}$ & $\mathrm{Sc}_{2} \mathrm{O}_{3}$ \\
\hline $\begin{array}{c}-60+80 \mathrm{mesh} / \\
\text { 1000G/M }\end{array}$ & 48.10 & 1.67 & 16.72 & 0.31 & 8.21 & 4.78 & 1.51 & 0.565 & 13.67 & 0.019 & 0.033 & 0.089 & 0.026 & 0.014 & 0.002 & 0.004 \\
$\begin{array}{c}-40+60 \mathrm{mesh} / \\
4000 \mathrm{G} / \mathrm{NM}\end{array}$ & 53.30 & 0.325 & 25.81 & 0.10 & 9.67 & 1.44 & 1.58 & 0.199 & 3.01 & 0.012 & 0.118 & 0.011 & 0.009 & 0.003 & 0.003 & 0.002 \\
\hline
\end{tabular}

Table 6. Mineral composition available within magnetic separation products and original sample

\begin{tabular}{|c|c|c|}
\hline Sample code & \multicolumn{2}{|c|}{ Mineral composition } \\
\hline Original sample, -80 mesh & $\begin{array}{l}\text { Magnesium calcium aluminum } \\
\text { iron silicate, } \\
\text { magnetite, sodium calcium } \\
\text { aluminum silicate }\end{array}$ & $\begin{array}{c}{\left[\mathrm{Ca}(\mathrm{Mg}, \mathrm{Fe}, \mathrm{Al})(\mathrm{Si}, \mathrm{Al})_{2} \mathrm{O}_{6}\right] ; \mathrm{Fe}_{3} \mathrm{O}_{4} ;} \\
(\mathrm{Ca}, \mathrm{Na})(\mathrm{Si}, \mathrm{Al})_{4} \mathrm{O}_{8}\end{array}$ \\
\hline $\begin{array}{l}\text { Non-magnetic product, - } \\
40+60 \text { mesh, } 4000 \mathrm{G}, \mathrm{NM}\end{array}$ & $\begin{array}{l}\text { Magnesium calcium aluminum } \\
\text { iron silicate, } \\
\text { magnetite, sodium calcium } \\
\text { aluminum silicate }\end{array}$ & $\begin{array}{c}{\left[\mathrm{Ca}(\mathrm{Mg}, \mathrm{Fe}, \mathrm{Al})(\mathrm{Si}, \mathrm{Al})_{2} \mathrm{O}_{6}\right] ; \mathrm{Fe}_{3} \mathrm{O}_{4} ;} \\
(\mathrm{Ca}, \mathrm{Na})(\mathrm{Si}, \mathrm{Al})_{4} \mathrm{O}_{8}\end{array}$ \\
\hline $\begin{array}{l}\text { Magnetic product, }-40+60 \\
\text { mesh, } 1000 \mathrm{G}, \mathrm{M}\end{array}$ & $\begin{array}{l}\text { Magnesium calcium aluminum } \\
\text { iron silicate, } \\
\text { magnetite, sodium calcium } \\
\text { aluminum silicate }\end{array}$ & $\begin{array}{c}{\left[\mathrm{Ca}(\mathrm{Mg}, \mathrm{Fe}, \mathrm{Al})(\mathrm{Si}, \mathrm{Al})_{2} \mathrm{O}_{6}\right] ; \mathrm{Fe}_{3} \mathrm{O}_{4} ;} \\
(\mathrm{Ca}, \mathrm{Na})(\mathrm{Si}, \mathrm{Al})_{4} \mathrm{O}_{8}\end{array}$ \\
\hline $\begin{array}{l}\text { Magnetic product, }-60+80 \\
\text { mesh } 1000 \mathrm{G}, \mathrm{M}\end{array}$ & $\begin{array}{l}\text { Magnesium calcium aluminum } \\
\text { iron silicate, } \\
\text { magnetite, sodium calcium } \\
\text { aluminum silicate }\end{array}$ & $\begin{array}{c}{\left[\mathrm{Ca}(\mathrm{Mg}, \mathrm{Fe}, \mathrm{Al})(\mathrm{Si}, \mathrm{Al})_{2} \mathrm{O}_{6}\right] ; \mathrm{Fe}_{3} \mathrm{O}_{4} ;} \\
(\mathrm{Ca}, \mathrm{Na})(\mathrm{Si}, \mathrm{Al})_{4} \mathrm{O}_{8}\end{array}$ \\
\hline
\end{tabular}




\section{CONCLUSIONS}

The particle size available within Cilacap iron sand mostly belonged to those that passed 40-mesh sieve. The obtained weight percentage from this sieve was $68.55 \%$ performing the total iron content of $2.91 \%$ and $1.74 \% \mathrm{TiO}_{2}$. The highest iron content was achieved at sieve of passing 80 mesh (11.62\%) but its weight decreased to $3.22 \%$.

The highest $\mathrm{Fe}$ and $\mathrm{TiO}_{2}$ contents were achieved by the particle size of $-40+60$ mesh, namely $14.39 \%$ and $2.28 \%$ respectively. The recovery was $20.08 \%$. Such a recovery was too low. Upgrading process required at least $59 \% \mathrm{Fe}$. However, this process has successfully increased the $\mathrm{TiO}_{2}$ content more than 5 times, from 0.325 to $1.67 \%$.

The results also showed some rare metal elements such as strontium (Sr), vanadium $(\mathrm{V})$, cobalt (Co), gallium (Ga), and scandium (Sc) present with the degree of concentration that is quite interesting. This data could be a preliminary study to research further the rare metal elements in abundance deposit of iron sand. The rare metal elements are important components in the formation of advanced materials which their role and needs will continue to increase in the future.

\section{ACKNOWLEDGEMENT}

The author wishes to thanks Chemical Laboratory of R\&D Centre for Mineral and Coal Technology for performing XRD and chemical analysis of the mineral sample. The author also wishes to express gratitude and deepest appreciation to Ir. Tatang Wahyudi, M.Sc. for his great help and valuable discussion.

\section{REFERENCES}

Adams, R. (2016) Drivers of demand for $\mathrm{TiO}_{2}$ feedstocks. Melbourne.

Ansori, C. (2013) "Mengoptimalkan perolehan mineral magnetik pada proses separasi magnetik pasir besi pantai selatan Kabupaten Kebumen, Jawa Tengah," Jurnal Teknologi Mineral dan Batubara, 9(3), pp. 145-156.
Arndt, N., Kesler, S. and Ganino, C. (2015) "Classification, distribution and uses of ores and ore deposits," in Metals and Society. 2nd Editio. Cham: Springer International Publishing, pp. 15-40. doi: 10.1007/978-3-319-17232-3_2.

Babu, N., Vasumathi, N. and Rao, R. B. (2009) "Recovery of ilmenite and other heavy minerals from teri sands (red sands) of Tamil Nadu, India," Journal of Minerals and Materials Characterization and Engineering, 8(2), pp. 149-159. doi: 10.4236/jmmce.2009.82013.

Barlow, E. (2015) A review of global supply and demand for titanium dioxide, PClMagazine (Paint and Coating Industry). Available at: http://www.pcimag.com/articles/100036a-review-of-global-supply-and-demandfor-titanium-dioxide (Accessed: July 17, 2016).

Bedinger, G. M. (2015) "Titanium and titanium dioxide." United State of America.

Beer, C., Stenderup, K., Wang, J., Sutherland, D. S. and Nyengaard, J. R. (eds.) (2015) Dermal abdorption of nanomaterials titanium dioxide and zinc oxide based sunscreen. Environmen. Copenhagen K: The Danish Environmental Protection Agency.

Gázquez, M. J., Bolívar, J. P., Garcia-Tenorio, R. and Vaca, F. (2014) "A review of the production cycle of titanium dioxide pigment," Materials Sciences and Applications, 5(7), pp. 441-458. doi: 10.4236/msa.2014.57048.

Justicia, I., Ordejón, P., Canto, G., Mozos, J. L., Fraxedas, J., Battiston, G. A., Gerbasi, R. and Figueras, A. (2002) "Designed self-doped titanium oxide thin films for efficient visible-light photocatalysis," Advanced Materials, 14(19), pp. 1399$1402 . \quad$ doi: 10.1002/15214095(20021002)14:19<1399::AIDADMA1399>3.0.CO;2-C.

Middlemas, S., Fang, Z. Z. and Fan, P. (2013) "A new method for production of titanium dioxide pigment," Hydrometallurgy, 131132, pp. 107-113. doi: 10.1016/j.hydromet.2012.11.002.

Premaratne, W. A. P. J. and Rowson, N. A. (2004) "Recovery of titanium from beach sand by physical separation," The European Journal of Mineral Processing and Environmental Protection, 4(3), pp. 183-193. 
Shaheed, M. A. and Hussein, F. H. (2015) "Preparation and Applications of Titanium Dioxide and Zinc Oxide Nanoparticles," Journal of Environmental Analytical Chemistry, 2(1), pp. 1-3. doi: 10.4172/JREAC.1000e109.

Sprong, C., Bakker, M., Niekerk, M. and Vennemann, F. (2015) Exposure assessment of the food additive titanium dioxide (E 171) based on use levels provided by the industry. Dutch: RIVM.

Sufiandi, D. (2011) "Konsentrasi pasir besi titan dari pengotornya dengan cara magnetik," Metalurgi (Majalah IImu dan Teknologi), 6(1), pp. 15-20. doi: 10.14203/mtl.v26i1.4.

Sunaryo and Sugihartono, I. (2010) "Pemisahan senyawa titanomagnetit Fe3-
xTixO4 $(0<x<1)$ dari pasir alam Indramayu, Jawa Barat," Makara Teknologi, 14(2), pp. 106-110.

Tampubolon, A. (2013) "The Indonesian titanium deposit types and their resources; The aspects for titanium commodity development," Buletin Sumber Daya Geologi, 8(3), pp. 100-110.

Whitfield, R., Brown, F., Wood, L. and Branco, J. (2016) The economic benefits of chlorine chemistry in titanium and titanium dioxide in the United States and Canada.

Zhang, W., Zhu, Z. and Cheng, C. Y. (2011) "A literature review of titanium metallurgical processes," Hydrometallurgy, 108(3-4), pp. 177-188. doi: 10.1016/j.hydromet.2011.04.005. 